\title{
Onion (Allium Cepa) Processing Waste as a Sorption Material for Removing Pollutants from Aqueous Media
}

\author{
Ildar G. Shaikhiev ${ }^{1(\mathbb{D})}$, Natalia V. Kraysman ${ }^{2, * \mathbb{D}}$, Svetlana V. Sverguzova ${ }^{3 \mathbb{C}}$ \\ 1 Department of Engineering Ecology; Institute of Chemical Engineering and Technology; Kazan National Research \\ Technological University; Kazan; Russian Federation; ildars@inbox.ru (I.G.S.); \\ 2 Department of Foreign Languages for Professional Communication; Institute of Innovation Management; Kazan National \\ Research Technological University; Kazan; Russian Federation; n_kraysman@mail.ru (N.V.K.); \\ 3 Department of Industrial Ecology; Institute of Chemical Engineering and Technology; Belgorod State Technological \\ University named after V.G. Shukhov; Belgorod; Russian Federation; pe @ intbel.ru (S.V.S.); \\ * Correspondence: n_kraysman@mail.ru (N.V.K.);
}

Scopus Author ID 56114338900

Received: 8.05.2021; Revised: 20.06.2021; Accepted: 26.06.2021; Published: 8.08.2021

\begin{abstract}
The paper summarizes the literature data on the use of onion (Allium cepa) processing waste as sorption materials to remove various pollutants (metal ions, dyes, antibiotics) from aqueous media. It provides brief literature data on the structure, volume of cultivation, and chemical composition of some components of onion biomass. It was found that onions contain many amino acids, vitamins, polyphenolic compounds, and other biologically active compounds that have various functional groups in their composition. This contributes to the removal of various metal ions $\left(\mathrm{Ca}^{2+} \mathrm{Cd}^{2+}, \mathrm{Cr}^{(\mathrm{VI}),} \mathrm{Cu}^{2+}, \mathrm{Hg}^{2+}\right.$, $\mathrm{Mg}^{2+}, \mathrm{Ni}^{2+}, \mathrm{Pb}^{2+}, \mathrm{Zn}^{2+}$ ) from aqueous media with native and modified onion processing waste (onion skin). The work shows the possibility of increasing the sorption characteristics of pollutants by treating the Allium сера biomass with various chemical reagents. It was found that the pollutant adsorption isotherms on onion skin are most often more accurately described by the Langmuir and Freundlich models, less often by other models. The kinetics of the process predominantly corresponds to the pseudo-second-order model. It was shown that the use of onion skin extracts modified with various chemical compounds is promising for removing heavy metal ions. The work also shows the possibility of using onion skin modified by plasma and microwave radiation to remove the Methylene blue dye from simulated solutions.
\end{abstract}

Keywords: onion skin; metal ions; dyes; antibiotics; adsorption; models of adsorption isotherms; thermodynamic parameters.

(C) 2021 by the authors. This article is an open-access article distributed under the terms and conditions of the Creative Commons Attribution (CC BY) license (https://creativecommons.org/licenses/by/4.0/).

\section{Introduction}

The pollution of the World Ocean with various pollutants is currently becoming catastrophic. The source of chemical compounds entering open water sources is untreated wastewater and stormwater. There are many methods to remove and dispose of pollutants from aquatic environments, including physicochemical, chemical, and biological treatment methods.

One effective way to extract pollutants from water media is the sorption method based on the absorption of chemicals by a solid surface due to physical or chemical interaction. Activated carbons currently used in industrial production are unprofitable due to the high cost and the need for regeneration.

The world community is currently developing a new innovative environmental protection area - the use of industrial and agricultural waste as reagents for removing pollutants 
from water environments. Of particular interest are cellulose-containing agricultural wastes studied as effective sorption materials to remove metal ions, oil and petrochemical products, dyes, pesticides, and other organic substances from aqueous media [1-20].

The scope of research is so large that recently subject reviews are regularly published on using a particular crop processing waste. Thus, in particular, information on the use of buckwheat waste [9], wheat waste [21], banana peel [22], tea waste [23-25], coffee waste [26], fruit peels [27], and waste [28] and others as sorption materials is summarized. The world literature provides information about using onion by-products as sorption materials for various pollutants, but this information is sketchy. In this regard, this review summarizes information about using these wastes as pollutant sorption materials from aqueous media.

\subsection{Brief information about the composition and ways of onion waste re-use.}

Almond (Prunus dulcis) is a shrub or small tree, subgenus Almond (Amygdalus), genus Prunus. The shrub (less commonly a small tree) is $4-6 m$ high, very branchy. There are two types of shoots: elongated vegetative and short generative. The leaves are petiolate, lanceolate, with a long-pointed tip.

Onion (Allium cépa) is a perennial herb, an Onion (Allium) species of the Onion (Alliaceae) family. Onions are one of the most important vegetable crops. The bulb is up to 15 $\mathrm{cm}$ in diameter, tunicated. The outer scales are dry, yellow, less often purple or white; the inner scales are fleshy, white, greenish, or purple, located on a shortened scape known as bottom. On the bottom, in the axils of juicy scales, there are buds that give rise to daughter bulbs that form a "nest" of several bulbs. The leaves are hollow, bluish-green. The flowering stem is up to $1.5 \mathrm{~m}$ tall, hollow, swollen, ending in a multi-flowered umbellate inflorescence. The flowers are set on long pedicels. The perianth is greenish-white, up to $1 \mathrm{~cm}$ in diameter, consisting of six leaflets, six stamens; the pistil has an upper three-celled ovary. The fruit is a capsule containing up to six seeds. The seeds are black, triangular, wrinkled, small. The plant blooms in June or July. The fruits ripen in August [29]. The volume of global onion production is more than 66 million tons per year [30].

Bulbs and leaves are used as a seasoning in the canning industry for salads, mushrooms, vegetable, and meat dishes, as well as as a spicy and vitamin appetizer and a flavoring additive to soups, sauces, gravies, minced meat. Most often, onions are eaten raw, fried in lard or vegetable oil until golden brown. Raw onions are added to sausage and meat products, farmer cheese, cheeses, bread with lard [29]. Onion processing waste is skins and trash. The need for recycled onions has increased in recent years, resulting in an increase in waste production (over 500,000 tons per year) [31]. The amount of solid onion waste (OSW) is really abundant and constitutes an environmental problem due to its pungent odor and the proliferated growth of phytopathogens.

The composition of the bulb and skin of the onion is given in [32]. It is indicated that, depending on the growth region, the bulb's moisture content is $88.6-92.8 \%$, the protein content is $0.9-1.6 \%$, acids content is up to $0.2 \%$, carbohydrates content is $5.2-9.0 \%$, ash content is $0.6 \%$. The amino acid content in the onion bulb is shown in Table 1.

Apart from amino acids, the following vitamins were identified in the bulb [32]: thiamine-3 mg / kg, riboflavine- $0.5 \mathrm{mg} / \mathrm{kg}$, nicotinic acid-2 mg/kg, C-100 mg/kg, folic acid$160 \mathrm{mg} / \mathrm{kg}$, biotin-9 mg/kg, and panthotenic acid-1.4 mg/kg.

It is indicated that the carbohydrate content is from 12 to $22 \mathrm{~g} / 100 \mathrm{~g}$ of dry bulb weight. In addition, anthocyanins, such as cyanidin-3-glucoside and cyanidin-3-diglucoside, peonidin- 
3-glucoside, were found in bulb composition. Such flavonols as quercetin, kaempferol, kaempferol-4-glucoside etc. have also been found [33]. A number of phenolic compounds (protocatechuic acid, phloroglucinol, pyrocatechol, etc.) and sterols and saponins have been identified in the bulb [32].

Table 1. Amino acids content in onion bulb [32].

\begin{tabular}{l|l}
\multicolumn{1}{c|}{ Amino Acid } & \multicolumn{1}{|c}{\begin{tabular}{c}
\multicolumn{1}{|c}{ Content, } \\
$\mathbf{m g} / \mathbf{1 0 0 g}$
\end{tabular}} \\
\hline Lysine & $4.2-18.8$ \\
Leucine & $1.9-15.9$ \\
Isoleucine & $1.9-13.1$ \\
Methionine & $<1.1$ \\
Phenylalanine & $2.4-10.6$ \\
Tyrosine & $2.6-6.5$ \\
Tryptophan & $0.8-3.6$ \\
Valine & $1.7-7.6$ \\
Arginine & $18-68$ \\
Histidine & $1.1-8.1$ \\
Alanine & $1.9-3.8$ \\
Aspartic acid & $18.6-24.9$ \\
Glycine & $1.1-2.2$ \\
Proline & $<0.8$
\end{tabular}

Considering the fact that dry onion skin has a humidity of 9.0-12.4\%, the content of biologically active substances in it is higher than that in the bulb. Studies have shown that onion skin can be used as an additive in bread [34], as piezoelectric elements [35]. Various ways of onion skin re-use have been proposed [36], including as a source for extracting fiber [37, 38], food ingredients [39], and tannic acids [40]. The possibility of obtaining such valuable compounds as flavonoids (quercetin, quercetin-3, 4'-O-diglucoside, quercetin-4'-Omonoglucoside, kaempferol, myricetin, and others) from onion skin was investigated [41-47]. Results indicate that solid onion waste and flavonol glycosides are potential antioxidants, antidiabetic, anticancer, and sedative agents [41]. The possibility was shown to use antioxidant compounds isolated from onion skins in functional bread production [48]. Isolation of flavonol quercetin and fructooligosaccharides from onion skin has been proposed [49, 50].

Onion processing waste can also be used to produce D-tagatose and bioethanol [51], bisphenols [52], bisindolylmethanes [53], acetic acid [54], etc.

\subsection{Using onion waste as sorption materials to remove metal ions and dyes from aqueous} media.

As mentioned above, onion processing waste includes many biologically active compounds with various functional groupings in their composition. This contributes to using onion skin as sorption materials to remove metal ions and dyes from aqueous media.

Metal ions. The biosorption potential of chemically modified onion skin (CMOS) for $\mathrm{Cd}^{2+}$ from its aqueous solutions at different conditions of initial ions concentration, contact time, $\mathrm{pH}$, and temperature was investigated under batch mode. For this purpose, $100 \mathrm{~g}$ of powdered onion skin were treated with $1000 \mathrm{ml}$ of $1 \mathrm{M}$ phosphoric acid and $2 \mathrm{sm} 3$ of $35 \%$ formaldehyde solution for $24 \mathrm{~h}$ and then kept in a water bath $\left(70{ }^{\circ} \mathrm{C}\right)$ for $30 \mathrm{~min}$. For CMOS, a maximum biosorption capacity (Qmax) of $18.34 \mathrm{mg} / \mathrm{g}$ was obtained compared to $11.90 \mathrm{mg} / \mathrm{g}$ for untreated onion skin. "The equilibrium biosorption data were analyzed by two-parameter (Langmuir, Freundlich, Temkin, and Dubinin-Radushkevich (D-R)), three-parameter (Redlich- 
Peterson, Sips, Toth, and Khan), and four-parameter (Baudu and Fritz-Schluender) isotherm models using linear and nonlinear regression methods. It was found that the most suitable isotherms for describing the biosorption data of the CMOS-system of $\mathrm{Cd} 2+$ ions are Freundlich, Sips, and Fritz-Schluender isotherms for two-, three- and four-parameter models, respectively [55]. The order of ranking is determined as follows: Fritz-Schluender $>$ Freundlich $>$ Temkin $>$ Langmuir $>$ Sips $>$ DR $>$ Khan $>$ Redlich-Peterson $>$ Baudu $>$ Toth.

The thermodynamic parameters of activation energy $(\mathrm{Ea}=33.10 \mathrm{~kJ} / \mathrm{mol})$, Gibbs free energy $(\Delta \mathrm{Go}=-5.48,-6.70$ and $-7.92 \mathrm{~kJ} / \mathrm{mol}$ at 303,313 and $323 \mathrm{~K}$, respectively), enthalpy $(\Delta \mathrm{Ho}=31.49 \mathrm{~kJ} / \mathrm{mol})$, and entropy change of biosorption $(\Delta \mathrm{So}=0.122 \mathrm{~kJ} / \mathrm{mol} \cdot \mathrm{K})$, by CMOS were evaluated and looked for that the biosorption process is feasible, spontaneous, endothermic and predominantly physical sorption process, although with some chemosorption element. The biosorption kinetics followed a pseudo-second-order kinetic model, and the biosorption mechanisms were controlled by boundary layer surface diffusion $[56,57]$.

The adsorption characteristics of $\mathrm{Pb}^{2+}$ ions on pre-boiled treated onion skins (PTOS) and formaldehyde-treated onion skins (FTOS) were evaluated. The effects of $\mathrm{Pb}^{2+}$ ions' initial concentration, agitation rate, solution $\mathrm{pH}$, and temperature on $\mathrm{Pb}^{2+}$ ions adsorption were investigated in batch systems. $\mathrm{Pb}^{2+}$ ions adsorption was found to increase with a rise in initial concentration. The point of zero net charges (PZC) was 6.53. The adsorption equilibrium data were best represented by the Langmuir isotherm model for FTOS and the Freundlich isotherm model for PTOS. As evaluated by the Langmuir isotherm, the maximum amount of $\mathrm{Pb} 2+$ ions adsorbed was $200 \mathrm{mg} / \mathrm{g}$ for FTOS. The efficiencies of PTOS and FTOS for $\mathrm{Pb}^{2+}$ ions removal were $84.8 \%$ and $93.5 \%$ at $0.75 \mathrm{~g} / \mathrm{dm} 3$ adsorbent dose, respectively, $(\mathrm{C} 0=50 \mathrm{mg} / \mathrm{dm} 3)$. It was found that the adsorption kinetics of $\mathrm{Pb}^{2+}$ ions obeyed the pseudo-first-order kinetic model. The activation energy (Ea) was obtained as $25.596 \mathrm{~kJ} / \mathrm{mol}$ [58].

In addition to metal cations, onion skin dust (OSD) has been studied to remove nitrate ions from simulated solutions. The experiment was confined to the effect of initial nitrate ion concentration, $\mathrm{pH}$, adsorbent dose, contact time, and temperature on the nitrate removal. The optimum $\mathrm{pH}$ for the maximum removal of nitrate-ions was $\mathrm{pH}=12.0$. Contact time of $10 \mathrm{~min}$ was selected as optimum contact time and used for all the other experiments. The maximum adsorption capacity of OSD was found to be $5.93 \mathrm{mg} / \mathrm{g}$. The adsorption equilibrium data nicely fitted with Langmuir isotherm with a very high goodness of fit $(\mathrm{R} 2=0.908)$. The values of thermodynamic parameters $\Delta \mathrm{H}^{\circ}, \Delta \mathrm{G}^{\circ}$ and $\Delta \mathrm{S}^{\circ}$ indicated that the nature of nitrate adsorption is dominated through endothermic, spontaneous, and feasible [59].

Experiments were conducted on the comparative adsorption of two or more onion skin metal ions. Thus, there was a study of $\mathrm{Cd}^{2+}$ and $\mathrm{Pb}^{2+}$ ions removal by onion skin modified with various reagents. In particular, an alumina-modified onion skin composite was synthesized, characterized, and used as an adsorbent to remove $\mathrm{Pb}^{2+}$ and $\mathrm{Cd}^{2+}$ ions from aqueous solutions via the adsorption process. The results obtained showed that at the optimum conditions of 200 $\mathrm{mg} / \mathrm{dm} 3$ initial metal ions concentration, $1.20 \mathrm{~g} / \mathrm{dm} 3$ adsorbent dosage, and $75 \mathrm{~min}$ contact time, the maximum removal percentages of $92.05 \%$ and $94.89 \%$ for $\mathrm{Pb}^{2+}$ and $\mathrm{Cd}^{2+}$ ions, appropriately, were obtained. Langmuir isotherm produced the best fit with values of monolayer uptake capacities as $9.74 \mathrm{mg} / \mathrm{g}$ and $14.17 \mathrm{mg} / \mathrm{g}$ for $\mathrm{Pb}^{2+}$ and $\mathrm{Cd}^{2+}$ ions, properly, and the pseudo-second-order kinetic model produced the best fit with the adsorption [60].

The sorption efficiency and mechanism of onion skin in both raw and modified form at the removal of $\mathrm{Cd}^{2+}, \mathrm{Cu}^{2+}$ and $\mathrm{Pb}^{2+}$ ions in an aqueous medium were investigated. The modification of the study material was done by anchoring ethylene-1,2-diamine. Experimental 
results confirmed that the metals' best sorption $\mathrm{pH}$ range ranged between $\mathrm{pH}=4.0-6.0$. It was also realized that the sorbent material could remove $90 \%$ of the metals within the first 20 min of contact. Found out that the three metal ions fitted best in the Langmuir model. The sorption capacities for $\mathrm{Pb}^{2+}, \mathrm{Cd}^{2+}$, and $\mathrm{Cu}^{2+}$ ions were found to be $71.85,68.03$, and $79.36 \mathrm{mg} / \mathrm{g}$ in the modified onion skin, respectively, and $87.49,96.99$, and $90.8 \mathrm{mg} / \mathrm{g}$ in the same order for the unmodified form. The resulting material was then applied to environmental water samples of varying concentrations $(\mathrm{C} 0=2-10 \mathrm{mg} / \mathrm{dm} 3)$. The maximum percent recoveries were determined as $87.8 \%, 80.6 \%$ and $77.1 \%$ for $\mathrm{Pb}^{2+}, \mathrm{Cd}^{2+}$ and $\mathrm{Cu}^{2+}$ ions, respectively [61].

Onion skin is greatly effective for binding heavy metal ions from aqueous solutions. Color leaching can be prevented, and the physical characteristics of the substrate can be ameliorated by treatment with formaldehyde in an acidic medium. Batch and column experiments have been led with $\mathrm{Cu}^{2+}, \mathrm{Cd}^{2+}, \mathrm{Zn}^{2+}, \mathrm{Ni}^{2+}, \mathrm{Hg}^{2+}$, and $\mathrm{Pb}^{2+}$. Almost quantitative removal of the metal ions from the solution can be achieved by using the treated onion skin columns. The competition of the different metal ions for the substrate has been examined. The capacity of the substrate in the majority of the metal ions investigated is well above $1 \mathrm{mg} / \mathrm{g}$. Thus, it was found that the sorption capacity for $\mathrm{Cu}^{2+}$ ions is $3.76 \mathrm{mg} / \mathrm{g}$ at the initial ion concentration in the solution of $100 \mathrm{ppm}$. For $\mathrm{Pb}^{2+}$ ions, this indicator was $10.9 \mathrm{mg} / \mathrm{g}(\mathrm{Co}=$ $110 \mathrm{ppm})$, for $\mathrm{Zn} 2+$ ions $-9.42 \mathrm{mg} / \mathrm{g}(\mathrm{Co}=100 \mathrm{ppm}), \mathrm{Cd}^{2+}-7.9 \mathrm{mg} / \mathrm{g}(\mathrm{Co}=80 \mathrm{ppm}), \mathrm{Hg}^{2+}$ $79.85 \mathrm{mg} / \mathrm{g}(\mathrm{Co}=800 \mathrm{ppm}), \mathrm{Ni} 2+-7.55 \mathrm{mg} / \mathrm{g}(\mathrm{Co}=100 \mathrm{ppm})[62]$.

The use of modified onion skins for binding $\mathrm{Ca}^{2+}$ and $\mathrm{Mg}^{2+}$ from solutions has been investigated. The effect of time of equilibration, temperature, and $\mathrm{pH}$ on the sorption of the metal ions has been studied. Batch and column experiments have been performed, and the adsorption isotherms have been plotted. The capacities with respect to $\mathrm{Ca}^{2+}$ and $\mathrm{Mg}^{2+}$ ions were found to be 4 and $16 \mathrm{mg} / \mathrm{g}$, respectively, of the substrate when separate column experiments were conducted using $1 \mathrm{dm}^{3}$ of a solution containing $1000 \mathrm{mg} / \mathrm{dm} 3$ of the respective metal ions at $\mathrm{pH}=6$. With a solution containing $10 \mathrm{mg} / \mathrm{dm} 3$ each of $\mathrm{Ca}^{2+}$ and $\mathrm{Mg}^{2+}$ ions together, however, the substrate seems to exhibit a greater preference for $\mathrm{Ca}^{2+}$ than $\mathrm{Mg}^{2+}$ ions. The sorbed metal ions from the substrate can be leached into a solution with a $0.1 \mathrm{~N}$ solution of $\mathrm{HCl}$, and the washed bed can be re-used [63].

The usage of polymerized onion skin to remove heavy metal ions from domestic and industrial wastewater to safe levels has been recommended as an inexpensive and productive alternative for commercial ion-exchange resins [62]. In view of the complex organic nature of the onion skin and its considerable capacity to bind $\mathrm{Ca}^{2+}$ and $\mathrm{Mg}^{2+}$ ions, the possibility of its use for preventing scale formation in boilers is indicated [63].

The preparation and properties of polymerized corn cob powder and its composite (with sawdust and onion skin) ion exchange resins for binding heavy ions have been described. Static (equilibrium) and dynamic (non-equilibrium) tests were carried out with solutions of $\mathrm{Pb}^{2+}, \mathrm{Ni}^{2+}$, $\mathrm{Cu}^{2+}, \mathrm{Mg}^{2+}, \mathrm{Zn}^{2+}$ and $\mathrm{Ca}^{2+}$ ions. Results showed that the concentrations of these metal ions were greatly reduced and the exchange capacity of the cation resin for the metal ions studied was of the order of $1 \mathrm{mg} / \mathrm{g}$. Therefore, the ion-exchange resin is an effective potential substitute for the expensive commercial resins used to treat metal-contaminated wastewater [64].

Also, the extract of onion skin was modified with various acids. The pulverized onion skin was subjected to extraction with acetone in a soxhlet extractor, and the extract was recovered from the extract-solvent mixture by evaporation. The extract was then treated with acids and studied as a sorption material to remove various metals from aqueous media. 
Red onion skin extract was chemically modified using thioglycolic acid to develop a suitable, low-cost, and efficient adsorbent to remove $\mathrm{Cd}^{2+}$ ions from aqueous solutions. Influences of temperature, contact time, initial concentration of ions, adsorbent dosage, and $\mathrm{pH}$ on the removal of $\mathrm{Cd}^{2+}$ ions were probed. Optimal adsorption conditions were found at $\mathrm{pH}=5$ and $\mathrm{pH}=4$, and 60- and 30-min equilibrium times for the modified and native onion skins. The equilibrium process was well described by the Freundlich isotherm model ( $\mathrm{R} 2=0.999)$. The maximum $\mathrm{Cd}^{2+}$ ions adsorption capacities from the Langmuir model are $21.28 \mathrm{mg} / \mathrm{g}$ (native) and $17.86 \mathrm{mg} / \mathrm{g}$ (modified). The adsorption process succeeded the mechanism physisorption. The pseudo-second-order rate equation fitted the kinetic data better than the pseudo-first-order rate equation for the two adsorbents. Thermodynamic parameters, such as $\Delta \mathrm{G}^{\circ}, \Delta \mathrm{H}^{\circ}$, and $\Delta \mathrm{S}^{\circ}$, were calculated for adsorption experimental studies. The results showed that the adsorption of $\mathrm{Cd}^{2+}$ ions on native/unmodified and modified onion skins was exothermic under the studied conditions [65].

There was a study of adsorption of $\mathrm{Cr}^{6+}$ ions by red onion skin extract resin waste modified with citric [58] and maleic [59] acids. The removal process was examined base on the effect of temperature ( 302 to $343 \mathrm{~K}$ ), initial ion concentration $\left(2\right.$ to $100 \mathrm{mg} / \mathrm{dm}^{3}$ ), and agitation time (10 to $60 \mathrm{~min}$ ). Data analysis from agitation time experiments demonstrated that equilibrium adsorption was achieved within 30 min. Maximum percentage adsorption was marked at $313 \mathrm{~K}$. The regression analysis of the models at different temperatures and concentrations was found to fit the experimental data in the order closely: Freundlich > Langmuir > Temkin. Investigation of the thermodynamic of adsorption reaction revealed values for change in enthalpy, Gibbs free energy, and entropy, reflecting the process spontaneity, exothermic nature, and feasible affinity of the interacting metal ions at the adsorption sites. Dubinin-Radushkevich isotherm was applied in studying the isotherm pathway, and it was observed that physisorption is the dominant pathway. Kinetic study showed that pseudo-second-order best describes the experimental data regarding

The removal of $\mathrm{Pb}^{2+}$ ions from synthetic wastewater by red onion skin extract modified with succinic acid was studied as a function of experimental parameters: contact time, $\mathrm{pH}$, and initial metal ion concentration. Maximum metal removal was observed at $\mathrm{pH}=6.3$, initial metal ion concentration of $20 \mathrm{mg} / \mathrm{dm}^{3}$, temperature of $28^{\circ} \mathrm{C}$, and 50 min contact time. Kinetic studies indicated that the adsorption of $\mathrm{Pb}^{2+}$ ions onto the modified extract followed a pseudo-secondorder kinetic model. The removal efficiency rate at the different temperatures is in the order: $28>40>50>60>70{ }^{\circ} \mathrm{C}$. The results obtained from the correlation coefficients of the plots indicated that Freundlich adsorption isotherm is the best fit for the experimental data. Calculations of thermodynamic parameters revealed that the sorption process was spontaneous ( $\Delta$ Go values of $-33.629,-20.867$, and $-5.402 \mathrm{~kJ} / \mathrm{mol}$ at 28,50 , and $70{ }^{\circ} \mathrm{C}$ respectively); and exothermic with a value of $\Delta H o$ as $-224.22 \mathrm{~kJ} / \mathrm{mol}$, while that of $\Delta$ So as $-630.4 \mathrm{~J} / \mathrm{mol} \cdot \mathrm{K}$. Results obtained from plotting the Dubinin-Radushkevich isotherm at different temperatures showed that the dominant mechanism responsible for removing $\mathrm{Pb}^{2+}$ ions was particle diffusion since the free energy values are in the range of $24.78-30.26 \mathrm{~kJ} / \mathrm{mol}$ for $28-70{ }^{\circ} \mathrm{C}$ [68].

Also, the extract of onion skin was modified with maleic, succinic, citric, and phosphoric acid. At an initial metal ion concentration of $20 \mathrm{mg} / \mathrm{dm}^{3}$, acid treatment increased $\mathrm{Cd}^{2+}$ ions removal rate from $59.3 \%$ to $75.95 \%, 92.0 \%, 94.0 \%$, and $98.45 \%$, respectively, and $\mathrm{Pb}^{2+}$ ions from $85.85 \%$ to $96.76 \%, 97.8 \%, 98.6 \%$, and $99.9 \%$ for onion skin samples modified with the corresponding acids. The exchange capacity for the modified and unmodified onion skins was higher for $\mathrm{Pb}^{2+}$ ions than for $\mathrm{Cd}^{2+}$ ions [69]. 
The findings from this study have revealed the application of a polyphenolic extract of red onion skin in the synthesis of exchange resin (CERR) for the uptake of $\mathrm{Mn}^{2+}, \mathrm{Fe}^{2+}$ and $\mathrm{Pb}^{2+}$ ions from an aqueous medium. The percentage metal ion uptake increased steadily with time at the initial stage, and thereafter, the values remained relatively constant from about 35 min for $\mathrm{Mn}^{2+}$ ions and $40 \mathrm{~min}$ for $\mathrm{Fe}^{2+}$ and $\mathrm{Pb}^{2+}$ ions. For the metal ions studied, a decrease in percentage exchange (from 86.69 to $46.92 \%$ for $\mathrm{Mn}^{2+}, 77.02$ to $46.74 \%$ for $\mathrm{Fe}^{2+}$ and 66.34 to $33.23 \%$ for $\mathrm{Pb}^{2+}$ ions) with temperature increase in the range of 29 to $70^{\circ} \mathrm{C}$ was observed, with the optimal exchange occurring at $29^{\circ} \mathrm{C}$. Examination of the mechanism of uptake of metal ions using CERR was conducted with Dubinin-Radushkevich isotherm model and showed that metal ions removal with CERR occurred by ion-exchange mechanism, with values of the mean free energy as $8.500,8.181$, and $8.248 \mathrm{~kJ} / \mathrm{mol}$ for $\mathrm{Mn}^{2+}, \mathrm{Fe}^{2+}$, and $\mathrm{Pb}^{2+}$ ions respectively [70].

Also, the investigation into the diffusion dynamics of $\mathrm{Mn}^{2+}, \mathrm{Fe}^{2+}$, and $\mathrm{Pb}^{2+}$ ions uptake from aqueous solution by chemically modified red onion skin extract was carried out. The polyhydroxylic extract of red onion skin was utilized in the synthesis of CERR. Predictions of the mechanism of diffusion dynamics were carried out by applying the data resolved from the fractional attainment of equilibrium at varied times into the Vermeulen diffusion models within the temperature range of 29 to $70^{\circ} \mathrm{C}$. The film diffusion coefficient values were lowest at $29^{\circ} \mathrm{C}$, indicating the most probable temperature condition for optimum exchange result with the CERR. Deductions from utilizing the Arrhenius type temperature dependence equation gave negative values of activation energy $\left(-7.223 \mathrm{~kJ} / \mathrm{mol}\right.$ for $\mathrm{Mn}^{2+}$ ions, $-6.898 \mathrm{~kJ} / \mathrm{mol}$ for $\mathrm{Fe}^{2+}$ ions and $-13.957 \mathrm{~kJ} / \mathrm{mol}$ for $\mathrm{Pb}^{2+}$ ions); which suggests that increase in temperature from 29 to $70^{\circ} \mathrm{C}$, lowered the rate of the exchange reaction [71].

The study concluded that onion skins, a waste material, have good potential as an adsorbent to remove toxic metal ions from water.

The dyes and other organic compounds have been several studies on the adsorption of dyes from simulated solutions with onion processing waste.

In particular, the use of cold plasma-treated and formaldehyde-treated onion skins as a biosorbent has been investigated to remove "methylene blue" dye from aquatic solutions. The impact of process variables such as adsorbent dosage, initial dye concentration, and $\mathrm{pH}$ were examined. The results indicated that the data for adsorption of methylene blue dye onto onion skins fitted well with the Langmuir isotherm model. The sorption capacities for cold plasmatreated and formaldehyde-treated onion skins by Langmuir isotherm were found to be 250 and $166.67 \mathrm{mg} / \mathrm{g}$, respectively. The equilibrium time was found to be $150 \mathrm{~min}$ for $50 \mathrm{mg} / \mathrm{dm} 3$ dye concentrations. The maximum removals for cold plasma-treated and formaldehyde-treated onion skins obtained were 90.94 and $95.54 \%$ at natural $\mathrm{pH}=10$ for adsorbent doses of 0.75 $\mathrm{g} / \mathrm{dm}^{3}$, respectively. The rates of sorption were found to conform to pseudo-first-order kinetics [72].

Varying the parameters, such as dye concentration, adsorbent dose, and $\mathrm{pH}$, carried out the potential feasibility of microwave heating treated and pre-boiling treated onion skins for removal of methylene blue. The amount of dye uptake increased with an increase in contact time, adsorbent dosage, and initial dye concentration. Lagergren's first-order and second-order were used to fit the experimental data. Based on the regression coefficient, the equilibrium data was found to fit the Langmuir equilibrium model better than other models. The adsorption capacities were found to be 142.67 , and $55.55 \mathrm{mg} / \mathrm{g}$ for microwave heating treated onion skins, and pre-boiling treated onion skins by Langmuir isotherm. The equilibrium time was found to be $150 \mathrm{~min}$ for $50 \mathrm{mg} / \mathrm{dm}^{3}$ dye concentrations. The maximum removals for microwave heating 
treated onion skins, and pre-boiling treated onion skins were obtained 86.34 and $94.13 \%$ at natural $\mathrm{pH}=10$ for adsorbent doses of $0.75 \mathrm{~g} / \mathrm{dm}^{3}$ [73].

A much higher sorption capacity was achieved when The onion membrane removed methylene blue. One gram of onion membrane was obtained from approximately $250 \mathrm{~g}$ of onion. The membranes ( $\sim \mathrm{g} / \mathrm{kg}$ of onion) were washed and rinse with distilled water to remove impurities. The amount of dye uptake increased with an increase in contact time, adsorbent dosage, and initial dye concentration. The adsorption capacity of the membrane was examined to be $1.055 \mathrm{~g} / \mathrm{g}$ with $84.45 \%$ efficiency after 1 hour and $1.202 \mathrm{~g} / \mathrm{g}$ with $96.20 \%$ efficiency after 8 hours in contact with a dye solution $\left(0.3 \mathrm{~g} / \mathrm{dm}^{3}\right)$. In addition, models of isotherm thermodynamics, kinetics, and adsorption were used to describe methylene blue adsorption processes. The results point out the data for adsorption of dye onto the membrane fitted well with the Freundlich isotherm and pseudo-second-order kinetic models. The Methylene blue adsorption from temperature to $\sim 50^{\circ} \mathrm{C}$ is spontaneous and thermodynamically favorable [74].

Results indicated that onion skins and membranes could be used as a biosorbent to remove methylene blue dye from contaminated waters. There was no literature data found on the study of other dyes' adsorption with onion processing waste.

Diclofenac and ibuprofen adsorption onto acids $\left(\mathrm{HCl}, \mathrm{H}_{2} \mathrm{SO}_{4}\right.$, and $\left.\mathrm{H}_{3} \mathrm{PO}_{4}\right)$ pre-treated onion skin (OS) was studied as a function of $\mathrm{pH}$, adsorbent dosage, drugs initial concentrations, and contact time. The $\mathrm{H}_{2} \mathrm{SO}_{4}$-OS showed higher drug adsorption efficiency, followed by others samples. Pseudo-second-order kinetic model fitted well to both the adsorption of the drug data. Freundlich isotherm explained well the adsorption of the drug onto native onion skin. The optimum $\mathrm{pH}$, adsorbent dosage, and contact time were $6.5,0.05 \mathrm{mg} / \mathrm{g}$, and $220 \mathrm{~min}$, respectively. At optimum condition, the diclofenac and ibuprofen adsorptions were 134.0 and $91.99 \mathrm{mg} / \mathrm{g}$, respectively, which were $81.90 \%$ and $65.99 \%$ removal of the initial concentrations [75].

\section{Conclusions}

In summary, the paper summarizes the literature data on the use of onion (Allium cepa) processing waste as sorption materials to remove various pollutants (metal ions, dyes, antibiotics) from aqueous media. It provides brief literature data on the structure, volume of cultivation, and chemical composition of some components of onion biomass. Data are given on removing various metal ions $\left(\mathrm{Ca}^{2+}, \mathrm{Cd}^{2+}, \mathrm{Cr}^{(\mathrm{VI})}, \mathrm{Cu}^{2+}, \mathrm{Hg}^{2+}, \mathrm{Mg}^{2+}, \mathrm{Ni}^{2+}, \mathrm{Pb}^{2+}, \mathrm{Zn}^{2+}\right)$ from aqueous media with native and modified onion processing waste, largely with onion skin. The work shows the possibility of increasing the sorption characteristics of pollutants by treating the Allium cepa wastes with various chemical reagents. It was found that the pollutant adsorption isotherms on onion waste are most often more accurately described by the Langmuir and Freundlich models. The kinetics of the process predominantly corresponds to the pseudosecond-order model. It was shown that the use of onion skin extracts modified with various chemical compounds is promising for removing heavy metal ions.

\section{Funding}

This research received no external funding.

\section{Acknowledgments}

This research has no acknowledgment. 


\section{Conflicts of Interest}

The authors declare no conflict of interest.

\section{References}

1. Panigrahi, T.; Santhoskumar, A.U. Adsorption process for reducing heavy metals in Textile Industrial Effluent with low cost adsorbents. Prog. Chem. Biochem. Res. 2020, 3, 135-139, https://doi.org/10.33945/SAMI/PCBR.2020.2.7.

2. Liu, Q.; Li, Y.; Chen, H.; Lu, J.; Yu, G.; Möslang, M.; Zhou, Y. Superior adsorption capacity of functionalised straw adsorbent for dyes and heavy-metal ions. J. Hazard. Mater. 2020, 382, 121040, https://doi.org/10.1016/j.jhazmat.2019.121040.

3. Yeow, P.K.; Wong, S.W; Hadibarata, T. Removal of Azo and Anthraquinone dye by plant biomass as adsorbent - A review. Biointerface Res. Appl. Chem. 2021, 11, 8218-8232, https://doi.org/10.33263/BRIAC111.82188232.

4. Kanthasamy, S.; Hadibarat, T.; Hidayat, T.; Alamri, S.A.; Al-Ghamdi, A.A. Adsorption of azo and anthraquinone dye by using watermelon peel powder and corn peel powder: equilibrium and kinetic studies. Biointerface Res. ApChem. 2020, 10, 4706-4713, https://doi.org/10.33263/BRIAC101.706713.

5. Halysh, V.; Sevastyanova, O.; Pikus, S.; Dobele, G.; Pasalskiy, B.; Gun'ko V.M.; Kartel, M. Sugarcane bagasse and straw as low-cost lignocellulosic sorbents for the removal of dyes and metal ions from water. Cellulose. 2020, 27, 8181-8197, https://doi.org/10.1007/s10570-020-03339-8.

6. Shaikh, T.M.A. Adsorption of $\mathrm{Pb}^{(\mathrm{II})}$ from wastewater by natural and synthetic adsorbents. Biointerface Res. ApChem. 2020, 5, 6522-6539, https://doi.org/10.33263/BRIAC105.65226539.

7. Chakraborty, R.; Asthana, A.; Singh, A.K.; Jain, B.; Susan, A.BH. Adsorption of heavy metal ions by various low-cost adsorbents: a review. Int. J. Environ. Analyt. Chem. 2020, 1-38, https://doi.org/10.1080/03067319.2020.1722811.

8. Chong S.N.; Hadibarata T. Adsorption of phenol red and remazol brilliant blue R by coconut shells (Cocos nucifera) and ambarella peels (Spondias dulcis). Biointerface Res. Appl. Chem. 2021, 11, 8564-8576, https://doi.org/10.33263/BRIAC111.85648576.

9. Shaikhiev, I.G; Sverguzova, S.V.; Galimova, R.Z.: Grechina, A.S. Using wastes of buckwheat processing as sorption materials for the removal of pollutants from aqueous media: A review. IOP Conf. Series: Mater. Science Eng. 2020, 945, 012044, 1-11, https://doi.org/10.1088/1757-899X/945/1/012044.

10. Sverguzova, S.V.; Shaikhiev, I.G.; Hunade, L. Study of modified peanut peel sorption properties relative to $\mathrm{Fe}^{(\mathrm{III})}$ ions. IOP Conf. Series: Earth Environ. Sci. 2020, 459, 042064, 1-6, https://doi.org/10.1088/17551315/459/4/042064.

11. Ali 1, A.; Ing, A.W.C.; Abdullah, W.R.W.; Hamzah, S.; Azaman, F. Preparation of high-performance adsorbent from low cost agricultural waste (Peanut husk) using full factorial design: application to dye removal. Biointerface Res. ApChem. 2020, 10, 6619-6628, https://doi.org/10.33263/BRIAC106.66196628.

12. Bhattacharjee, C.; Dutta, S.; Saxena, V.K. A review on biosorptive removal of dyes and heavy metals from wastewater using watermelon rind as biosorbent // Environ. Adv. 2020, 2, 100007, 1-13, https://doi.org/10.1016/j.envadv.2020.100007.

13. Vasu, D.; Kumar, S.; Walia, Y.K. Removal of dyes using wheat husk waste as a low-cost adsorbent. Environ. Claims J. 2020, 32, 67-76, https://doi.org/10.1080/10406026.2019.1669908.

14. Thakur, V.; Sharma, E.; Guleria, A.; Sangar, S.; Singh, K. Modification and management of lignocellulosic waste as an ecofriendly biosorbent for the application of heavy metal ions sorption. Mater. Today: Proceed. 2020, 32, 608-619, https://doi.org/10.1016/j.matpr.2020.02.756.

15. Agarwal, A.; Upadhyay, U.; Sreedhar, I., Singh, S.A.; Patel, C.M. A review on valorization of biomass in heavy metal removal from wastewater. J.Water Proc. Eng. 2020, 38, 101602, https://doi.org/10.1016/j.jwpe.2020.101602.

16. Dhaouadi, F.; Sellaoui, L.; Chávez-González, B.; Reynel-Ávila, H.E.; Diaz-Muñoz, L.L.; Mendoza-Castillo, D.I.; Bonilla-Petriciolet, A.; Lima, E.C.; Tapia-Picazo, J.C.; Lamine, A.B. Application of a heterogeneous physical model for the adsorption of $\mathrm{Cd}^{2+}, \mathrm{Ni}^{2+}, \mathrm{Zn}^{2+}$ and $\mathrm{Cu}^{2+}$ ions on flamboyant pods functionalized with citric acid. Chem. Eng. J. 2020, 127975, https://doi.org/10.1016/j.cej.2020.127975. 
17. Çelebi, H.; Gök, G.; Gök, O. Adsorption capability of brewed tea waste in waters containing toxic lead(II), cadmium (II), nickel (II), and zinc(II) heavy metal ions. Sci. Rep. 2020, 10, 17570, 1-12, https://doi.org/10.1038/s41598-020-74553-4.

18. Saravanan, A.; Sundararaman, T.R.; Jeevanantham, S.; Karishma, S.; Kumar, P.S.; Yaashikaa, P.R. Effective adsorption of $\mathrm{Cu}^{(\mathrm{II})}$ ions on sustainable adsorbent derived from mixed biomass (Aspergillus campestris and agro waste): Optimization, isotherm and kinetics study. Groundwater Sustain. Develop. 2020, 11, 100460, https://doi.org/10.1016/j.gsd.2020.100460.

19. Lestari, A.Y.D.; Hapsari, A.R.; Chafidz, A.; Elnaufal, W.D.; Indri, S.N.; Alatas, M.M.; Mulyono, S. Magnetically modified corn cob as a new low-cost biosorbent for removal of $\mathrm{Cu}$ (II) and $\mathrm{Zn}$ (II) from wastewater. Jurnal Bahan Alam Terbarukan. 2020, 9, 96-102, https://doi.org/10.15294/jbat.v9i2.27136.

20. Zhang, W.; Duo, H.; Li, S.; An, Y.; Chen, Z.; Liu, Z.; Ren, Y.; Wang, S.; Zhang, X.; Wang, X. An overview of the recent advances in functionalization biomass adsorbents for toxic metals removal. Colloid Interface Sci. Commun. 2020, 38, 100308, https://doi.org/10.1016/j.colcom.2020.100308.

21. Farooq, U.; Kozinski, J.A.; Khan, M.A.; Athar, M. Biosorption of heavy metal ions using wheat based biosorbents - A review of the recent literature. Biores. Technol. 2010, 101, 5043-5053, https://doi.org/10.1016/j.biortech.2010.02.030.

22. Akpomie, K.G.; Conradie, J. Banana peel as a biosorbent for the decontamination of water pollutants. A review. Environ. Chem. Lett. 2020, 18, 1085-1112, https://doi.org/10.1007/s10311-020-00995-x.

23. Wasewar, K.L. Adsorption of metals onto tea factory waste: a review. Int.J. Res.Reviews App. Sci. 2010, 3, 303-322,

https://www.researchgate.net/publication/45627731_Adsorption_of_metals_onto_tea_factory_waste_A_rev iew.

24. Hussain, S.; Anjali, K.P.; Hassan, S.T.; Dwivedi, P.B. Waste tea as a novel adsorbent: a review. Appl. Water Sci. 2018, 8, 165, https://doi.org/10.1007/s13201-018-0824-5.

25. Nandal, M.; Rajni Hooda, R.; Dhania, G. Tea Wastes as a Sorbent for Removal of Heavy Metals from wastewater. Int. J. Current Eng. Technol. 2014, 4, 243-247, https://citeseerx.ist.psu.edu/viewdoc/download?doi=10.1.1.1091.7458\&rep=rep1\&type=pdf.

26. Anastopoulos, I.; Karamesouti, M., Mitropoulos, A.C.; Kyzas, G.Z. A review for coffee adsorbents. J. Molec. Liq. 2017, 229, 555-565, https://doi.org/10.1016/j.molliq.2016.12.096.

27. Bhatnagar, A.; Sillanpää, M.; Witek-Krowiak, A. Agricultural waste peels as versatile biomass for water purification - A review. Chem. Eng. J. 2015, 270, 244-271, https://doi.org/10.1016/j.cej.2015.01.135.

28. Othman, N.; Mohd-Asharuddin, S.; Azizul-Rahman, M.F.H. An overview of fruit waste as sustainable adsorbent for heavy metal removal. App. Mechanics Mater. 2013, 389, P. 29-35, https://doi.org/10.4028/www.scientific.net/AMM.389.29.

29. D. A. De Mason. Morphology and anatomy of Allium. In: Onions and Allied Crops: Volume I: Botany, Physiology, and Genetics. Edited by H. D. Rabinowitch, J. L. Brewster. 2018. vol. 1. CRC Press, Boca Raton, Fl. P. 27-51.

30. Ren, F. Effects of pre and post-harvest treatments on the phenolic compounds and antioxidant activity of different onion varieties. PhD Thesis, University College Cork, Ireland. 2019.251 , https://cora.ucc.ie/handle/10468/8360.

31. Michalak-Majewska, M.; Teterycz, D.; Muszyński, S.; Radzki, W.; Sykut-Domańska, E. Influence of onion skin powder on nutritional and quality attributes of wheat pasta. PLOS ONE. 2020, 15, e0227942, 1-15, https://doi.org/10.1371/journal.pone.0227942.

32. Fenwick, G.R.; Hanley, A.B. Chemical composition. In: Onions and Allied Crops. Biochemistry Food Science Minor Crops. 1989, 3, 18-28, https://www.taylorfrancis.com/chapters/edit/10.1201/97804293557524/processing-alliums-use-food-manufacture-fenwick-hanley.

33. Ren, F.; Nian, Y.; Perussello, C.A. Effect of storage, food processing and novel extraction technologies on onions flavonoid content: A review. Food Res. Int. 2020, 132, 108953, 1-11, https://doi.org/10.1016/j.foodres.2019.108953.

34. Gawlik-Dziki, U.; Kaszuba, K.; Piwowarczyk, K.; Świeca, M.; Dziki, D.; Czyż, J. Onion skin - raw material for the production of supplement that enhances the health-beneficial properties of wheat bread. Food Res. Int. 2015, 73, 97-106, http://dx.doi.org/10.1016/j.foodres.2015.02.008.

35. Maitia, S.; Karanb, S.K.; Lee, J.; Mishra, A.K.; Khatua, B.B.; Kim, J.K. Bio-waste onion skin as an innovative nature-driven piezoelectric material with high energy conversion efficiency. Nano Energy. 2017, 42, 282293, https://doi.org/10.1016/j.nanoen.2017.10.041. 
36. Sharma, K.; Mahato, N.; Nile, S.H.; Leeb, E.T.; Lee, Y.R. Economical and environmentally-friendly approaches for usage of onion (Allium cepa L.) waste. Food Funct. 2016, 7, 3354, 1-16, http://dx.doi.org/10.1039/c6fo00251j.

37. Benítez, V.; Mollá, E.; Martín-Cabrejas, M.A.; Aguilera, Y.; M. Esteban, R.M. Physicochemical properties and in vitro antidiabetic potential of fibre concentrates from onion by-products. J. Funct. Foods. 2017, 36, 34-42, http://dx.doi.org/10.1016/j.jff.2017.06.045.

38. Reddy, J.P.; Rhim, J-W. Extraction and characterization of cellulose microfibers from agricultural wastes of onion and garlic. J. Natur. Fibers. 2018, 15, 465-473, http://dx.doi.org/10.1080/15440478.2014.945227.

39. Cebin, A.V.; Šeremet, D.; Mandura, A.; Martinić, A.; Komes, D. Onion solid waste as a potential source of $\begin{array}{llllll}\text { functional food } \quad \text { ingredients. } & \text { Eng. } & \text { Power. } & \mathbf{2 0 2 0}, & \text { 15, }\end{array}$ https://hrcak.srce.hr/index.php?show=clanak\&id_clanak_jezik=355815.

40. Sukor, N.F.; Selvam, V.P.; Jusoh, R.; Kamarudin, N.S.; Rahim, S.A. Intensified DES mediated ultrasound extraction of tannic acid from onion peel. J. Food Eng. 2021, 296, 110437, 1-11, https://doi.org/10.1016/j.jfoodeng.2020.110437.

41. Nile, A.; Nile, S.H.; Kim, D.H.; Keum, Y.S.; Seok, P.G.; Sharma, K. Valorization of onion solid waste and their flavonols for assessment of cytotoxicity, enzyme inhibitory and antioxidant activities. Food Chem. Toxicol. 2018, 119, 281-289, https://doi.org/10.1016/j.fct.2018.02.056.

42. Kim, S-W.; Ko, M-J.; Chung, M-S. Extraction of the flavonol quercetin from onion waste by combined treatment with intense pulsed light and subcritical water extraction. J. Clean. Product. 2019, 231, 1192-1199, https://doi.org/10.1016/j.jclepro.2019.05.280.

43. Rodrigues, A.S.; Almeida, D.P.F.; Simal-Gándara, J.; Pérez-Gregorio, M.R. Onions: A Source of Flavonoids. In: Flavonoids - from biosynthesis to human health. 2017, 438-472, https://dx.doi.org/10.5772/intechopen.69896.

44. Stefou, I.; Spyros Grigorakis, S.; Loupassaki, S.; Makris, D.P. Development of sodium propionate-based deep eutectic solvents for polyphenol extraction from onion solid wastes. Clean Technol. Environ. Policy. 2019, 21, 1563-1574, https://doi.org/10.1007/s10098-019-01727-8.

45. Pal, C.B.T.; Jadeja, G.C. Deep eutectic solvent-based extraction of polyphenolic antioxidants from onion (Allium cepa L.) peel. J. Sci. Food Agric. 2019, 99, 1969-1979, https://doi.org/10.1002/jsfa.9395.

46. Benito-Román, O.; Blanco, B.; Sanz, M.T.; Beltrán, S. Subcritical water extraction of phenolic compounds from onion skin wastes (Allium cepa cv. Horcal): Effect of temperature and solvent properties. Antioxidants. 2020, 9, 1233, 1-18, https://doi.org/10.3390/antiox9121233.

47. Munir, M.T.; Kheirkhah, H.; Baroutian, S.; Quek, S.Y.; Young, B.R. Subcritical water extraction of bioactive compounds from waste onion skin. J. Clean. Product. 2018, 183, 487-494, https://doi.org/10.1016/j.jclepro.2018.02.166.

48. Piechowiak, T.; Grzelak-Błaszczyk, K.; Bonikowski, R.; Balawejder, M. Optimization of extraction process of antioxidant compounds from yellow onion skin and their use in functional bread production. LWT - Food Sci. Technol. 2020, 117, 108614, 1-7, https://doi.org/10.1016/j.lwt.2019.108614.

49. Santiago, B.; Calvo, A.A.; Gullyn, B.; Feijoo, G.; Moreira, M.T.; Gonzalez-Garcia, S. Production of flavonol quercetin and fructooligosaccharides from onion (Allium cepa L.) waste: An environmental life cycle approach. Chem. Eng. J. 2020, 392, 123772, 1-11, https://doi.org/10.1016/j.cej.2019.123772.

50. Choi, I.S.; Cho, E.J.; Moon, J-H.; Bae, H-J. Onion skin waste as a valorization resource for the by-products quercetin and biosugar. Food Chem. 2015, 188, 537-542, https://dx.doi.org/10.1016/j.foodchem.2015.05.028.

51. Kim, H.M.; Song, Y.; Wi, S.G.; Bae, H-J. Production of D-tagatose and bioethanol from onion waste by an intergrating bioprocess. J. Biotechnol. 2017, 260, 84-90, https://dx.doi.org/10.1016/j.jbiotec.2017.09.013.

52. Chia, P.W.; Lim, B.S.; Yong, F.S.Y.; Poh, S-C.; Kan, S-Y. An efficient synthesis of bisenols in water extract of waste onion peel ash. Environ. Chem. Lett. 2018, 16, 1493-1499, https://doi.org/10.1007/s10311-0180764-1.

53. Chia, P.W.; Lim, B.S.; Tan, K.C.; Yong, F.S.J.; Kan, S-Y. Water extract of onion peel for the synthesis of bisindolylmethanes. J. King Saud Univ. - Sci. 2019, 31, 642-647, https://doi.org/10.1016/j.jksus.2018.05.029.

54. Kim, H.M.; Choi, I.S.; Lee, S.; Yang, J.E.; Jeong, S-G.; Park, S.J.H.; Ko, S.H.; Hwang, I.M.; Chun, H.H.; Wi, S.G.; Kim, J-C.; Park, H.W. Biorefining process of carbohydrate feedstock (agricultural onion waste) to acetic acid. ACS Omega. 2019, 4, 22438-22444, https://doi.org/10.1021/acsomega.9b03093. 
55. Agarry, S.E.; Ogunleye, O.O.; Ajani, O.A. Biosorptive removal of cadmium (II) Ions from aqueous solution by chemically modified onion skin: batch equilibrium, kinetic and thermodynamic studies, Chem. Eng. Commun. 2015, 202, 655-673, https://doi.org/10.1080/00986445.2013.863187.

56. Olasehinde, E.F; Adegunloye, A.V.; Adebayo, M.A.; Oshodi, A.A. Cadmium (II) adsorption from aqueous solutions using onion skins. Water Conservat. Sci. Eng. 2019, 4, 175-185, https://doi.org/10.1007/s41101019-00077-2.

57. Chowdhury, A.; Bhowal, A.; Datta, S. Equilibrium, thermodynamic and kinetic studies for removal of copper (II) from aqueous solution by onion and garlic skin. Water, 2012, 4, 37-51, https://www.researchgate.net/publication/290484592_Equilibrium_thermodynamic_and_kinetic_studies_fo r_removal_of_copper_II_from_aqueous_solution_by_onion_and_garlic_skin.

58. Saka, C.; Şahin, Ö.; Demir, H.; Kahyaoğlu, M. Removal of lead(II) from aqueous solutions using pre-boiled and formaldehyde-treated onion skins as a new adsorbent. Separ. Sci. Technol. 2011, 46, 507-517, https://doi.org/10.1080/01496395.2010.517595.

59. Mondal, N.K.; Ghosh, P.; Sen, K.; Mondal, A.; Debnath, P. Efficacy of onion peel towards removal of nitrate from aqueous solution and field samples. Environ. Nanotechnol. Monit. Manag. 2019, 11, 100222, 1-7, https://doi.org/10.1016/j.enmm.2019.100222.

60. Yusuff, A.S.; Owolabi, J.O.; Igbomezie, C.O. Optimization of process parameters for adsorption of heavy metals from aqueous solutions by alumina-onion skin composite. Chem. Eng. Commun. 2019, 1-15, https://doi.org/10.1080/00986445.2019.1680371.

61. Waweru, B.W.; Mwangi, I.W.; Murungi, J.; Wanjau, R.N.; Msagati, T.A.M.; Manohah, R. Remediation of lead, cadmium and copper polluted waters by onion skins (Allium cepa). Int. J. Agricult. Innovat. Res. 2016, 4, 932-943, https://ir-library.ku.ac.ke/handle/123456789/15210.

62. Kumar, P.; Dara, S.S. Binding heavy metal ions with polymerized onion skin. J. Polym. Sci.: Polym. Chem. Edit. 1981, 19, 397-402, https://doi.org/10.1002/pol.1981.170190216.

63. Bankar, D.B.; Dara, S.S. Binding of calcium and magnesium by modified onion skins. J. Appl. Polym. Sci. 1982, 27, 1727-1733, https://doi.org/10.1002/app.1982.070270529.

64. Odozi, T.O.; Okele, S.; Lartey, R.B. Studies on binding metal ions with polymerized corn cob and a composite resin with sawdust and onion skin. Agricult. Wastes. 1985, 12, 13-21, https://doi.org/10.1016/0141-4607(85)90041-1.

65. Ikodiya, O.; Ibezim-Ezeani, M.U.; Sorption studies on the remediation of cadmium (II) ions contaminated water using succinic acid modified red onion skin extract. Int. J. Innovat. Res. Develop. 2017, 6, 117-127, https://www.researchgate.net/publication/334042259_Sorption_Studies_on_the_Remediation_of_Cadmium _II_Ions_Contaminated_Water_Using_Succinic_Acid_Modified_Red_Onion_Skin_Extract.

66. Chibuike, O.; Ibezim-Ezeani, M.U.; Onyewuchi, A. Tri-carboxylic acid red onion (Allium cepa) skin extract resin for the removal of chromium (VI) ion from aqueous solution. Modern Chem. Appl. 2019, 7, 1-9, https://doi.org/10.4172/2329-6798.1000266.

67. Chibuike, O.; Ibezim-Ezeani, M.U. Chromium (VI) ion adsorption onto maleic acid red onion skin extract resin (MRER) in aqueous solution. Pakistan J. Sci. Ind. Res. Ser. A. Phys. Sci. 2019, 62A, 135145, https://doi.org/10.52763/PJSIR.PHYS.SCI.62.3.2019.135.145.

68. Ibezim-Ezeani, M.U.; Orji, I. Kinetic and equilibrium studies on lead (II) ion removal from aqueous solution using succinic acid modified red onion skin extract. Int. J. Sci. Eng. Tech. Res. 2017, 6, 367-374, https://www.researchgate.net/publication/334042422_Kinetic_and_Equilibrium_Studies_on_Lead_II_Ion_ Removal_from_Aqueous_Solution_Using_Succinic_Acid_Modified_Red_Onion_Skin_Extract.

69. Orji, I.; Ibezim-Ezeani, M.U.; Akaranta, O. Utilization of red onion skin extract for remediation of lead (II) and cadmium (II) ions from aqueous solution. Int. J. Enhanc. Res. Sci. Technol. Eng. 2016, 5, 283-291, https://www.researchgate.net/publication/334041979_Utilization_of_Red_Onion_Skin_Extract_for_Remed iation_of_Lead_II_and_Cadmium_II_Ions_from_Aqueous_Solution.

70. Ibezim-Ezeani, M.U.; Okon, A.F. Sorption mechanism of metal ions uptake from aqueous medium by chemically modified red onion (Allium cepa) skin extract. Res. J. Chem. Sci. 2016, 6, 49-54, http://isca.me/rjcs/Archives/v6/i9/8.ISCA-RJCS-2016-204.pdf.

71. Ibezim-Ezeani, M.U.; Akaranta, O. Diffusion dynamics of metal ions uptake at the carboxylatedepichlorohydrin red onion skin extract resin - aqueous interface. Int. J. Eng. Res. Applicat. 2017, 7, 46-52, https://doi.org/10.9790/9622-0703014652. 
72. Saka, C.; Sahin, Ö. Removal of methylene blue from aqueous solutions by using cold plasma- and formaldehyde-treated onion skins. Color. Technol. 2011, 127, 246-255, https://doi.org/10.1111/j.14784408.2011.00306.x.

73. Saka, C.; Şahin, Ö.; Çelik, M.S. The removal of Methylene blue from aqueous solutions by using microwave heating and pre-boiling treated onion skins as a new adsorbent. Energy Sources, Part A: Recovery, Utilizat. Environ. Effects, 2012, 34, 1577-1590, https://doi.org/10.1080/15567036.2010.525598.

74. Saber-Samandari, S.; Heydaripour, J. Onion membrane: an efficient adsorbent for decoloring of wastewater. J. Environ. Health Sci. Eng. 2015, 13, 1-11, https://doi.org/10.1186/s40201-015-0170-6.

75. Abbas, G.; Javed, I.; Iqbal, M.; Haider, R.; Hussain, F.; Qureshi, N. Adsorption of non-steroidal antiinflammatory drugs (diclofenac and ibuprofen) from aqueous medium onto activated onion skin. Desalin. Water Treat. 2017, 1-12, https://doi.org/10.5004/dwt.2017.21465. 